\title{
THE USE OF CATHEDRALS
}

IF I use the personal pronoun very often throughout this paper, I hope it will not be attributed to aggressive egoism. My reason is quite a different one. To write as "we" always seems to me, for an ordinary person, absurdly pompous; and, indeed, I have no claim to represent anyone but myself. So I propose to say "I think," "I believe," and so on, because I am only stating my own individual opinion. I am quite aware that I may be often wrong. It is quite likely that, if I live much longer, I may change some of my views through experience or better information. I am not sure whether I am not too old to teach. I hope I am not too old to learn.

To anyone who wishes to study the past history of cathedrals in connection with their usefulness to-day, I would venture to recommend a few books, being far from an exhaustive list. These are: Mr. E. A. Freeman's Wells; Archbishop Benson's The Cathedral: Its Necessary Place in the Life and Work of the Church; Canon Newbolt's The Living Power of a Cathedral; and then, for practical illustration of what such a church may be in the lives of good men, Dr. Liddon's Walter Kerr Hamilton and Dr. Gregory's Autobiography.

The first thing to be said, and the one thing never to be forgotten, is that cathedral churches were built, and still exist, not for any bishops, or chapters, or choirs, or musicians whatever, but for the glory of God. They are to be the expression, in the most complete, most exquisite, most devoted achievement of which man is capable, of the reverence of humanity for the Divine, of the offering of body, soul, and spirit to the Almighty Father, to His only Son our Lord, to the Spirit of Sanctification, the ever blessed and adorable Trinity. That is the thought which we whose lot is cast in the great churches should never allow to sink into the background of our minds. That is the thought which should inspire all our work and all our prayers. If only that thought can be burnt into our hearts by the fire of the Holy Spirit, there will no longer be complaints of uselessness or dreariness or formalism or theatricalism. Men will see from our worship that these glorious buildings are used day by day continually as the homes of God on earth. So we shall not fear criticism over our work or our aims, individual or corporate, whether it be intelligent or malicious. Rather we shall learn something from all that is said against us, because we learn most of all from our daily converse with God. 
The motto of all who serve in cathedral churches must be, "Lord, I have loved the habitation of Thy House-because it is Thine-and the place where Thine honour dwelleth."

I should like to quote some words I wrote a few years ago when it was my privilege to edit the Autobiography of Dr. Gregory, Dean of S. Paul's. (I wish everyone who has to do with cathedrals would read what Dr. Gregory wrote; but I am sorry to find that the book is out of print.) I had noted the wonderful record of Dr. Gregory's attendances at morning and evening prayers every week-day throughout the year, and I added: "Such a record of attendance as the Dean's is but one of the many proofs that he was indeed at home at S. Paul's. He felt very keenly that the work of a cathedral, rightly done, was enough to occupy any man. Archbishop Benson, in his book The Cathedral, had set out the need of such single-hearted devotion, and insisted that not only should the "universal old perpetual or "major residence" of two-thirds of the year at least,' be restored, but that the majores personce, Precentor, Chancellor, Sub-Dean, Treasurer, or the like, with the Archdeacon, should be the residentiaries, and charged with the definite duties of their stalls, as had indeed been the practice even in the eighteenth century, 'the Chancellor lecturing from time to time, and the Precentor invariably ordering the service."* This was the view also of Dr. Gregory. He knew that it was difficult, if not impossible, to obtain a consistent policy in regard to the functions of a cathedral from those who were only occasionally resident, and he $\mathrm{knew}$ that those who were compelled by their duties to reside and to attend certain services, were not likely to do more than was actually required of them if their superior officers were content to give a minimum of residence and worship."

It is the superior officials of the Church who must set the example. In order to do so they must run counter to a persistent tendency of to-day. Canon Newbolt has said very truly that "we are living to see the growth of a grudging spirit towards God in the matter of the time which we devote to His service," but " it is a sorry thing to worship God with a grudging heart, to be for ever asking when will the new moon be gone, that we may sell corn, and the Sabbath that we may set forth wheat? It is quite possible that God may be asking a tithe of our time as well as a tithe of our money."

There has never been a better Dean in recent times than was Henry Charles Beeching at Norwich-a true scholar, a wise

\footnotetext{
* This, of course, would only apply where the Precentor was a Major Canon, or where the statutes give him this power. The Organist must certainly not be ignored (nor even the Dean).
} 
and good man. He was once asked to set down a motto for a day. He wrote:

For every man hath business and desire

Such as it is ; and for mine own poor part, Look you, I'll go pray.

It is right that some at least of the officers of the cathedral should also work outside, as their office calls them and as their Bishop may direct; but we who serve in cathedrals should be, first of all, men of prayer. There is no work for God that may not spring from that.

It must be our care to see that no possible opportunity for prayer for any person at any time is lost by our neglect. Thus our first duty is to see that the daily services of worship are frequent, reverent, and at suitable times. To most cathedral cities there are constant visitors; in almost all there is a devoted body of habitual worshippers. Thus there should be a daily celebration of the Holy Communion, at which may be offered intercession for every district in the diocese in turn, as well as for special objects and special needs. Continually among the familiar faces we find newcomers, folk passing through on a journey, in sorrow, at some particular crisis of life, drawing nigh to God. These value more than we can guess their communion with us. The expression of man's dedication of the cathedrals is the perpetual round of divine worship. Canon Newbolt has quoted a saying of Bishop Harvey Goodwin, when he was himself a Dean: "The principal feature of a cathedral is the maintenance of a daily service on a grand scale." That was the aim of those who built these splendid fabrics: it is the object with which those who love them seek to preserve their system in an age which (often very ineffectively) seeks efficiency, and rarely looks beyond a practical utilitarianism. We whose work lies in the cathedrals believe that it is our duty as well as our privilege to show forth the glory of God, to reflect His majesty, however dimly and in enigma, in the most beautiful, most stately, and most complete manner that lies within our power. And we thus act, not for ourselves, but on behalf of all our brethren of the whole Body of Christ on earth. With all our hearts we echo the words of Dean Church: "It is not for ourselves, it is for the whole body of those for whom Christ died and rose again that, for their sakes and in their name, we in a place like this offer to Him of our best, that we adorn His house with majesty and beauty, that we fill its courts with glorious music. For them, in such places as this, we understand that we are bound to meet their longings for what is beautiful."

The worship of a cathedral must be beautiful no less than it must be constant. It is for this reason that $I$ for one so greatly 
regret that in some places it seems for the present necessary to restrict in number the musical services which for centuries have been the characteristic offering of our English cathedrals. The difficulties of their continuance are well known: the diminishing funds of the Chapters; the necessarily rising salaries of the musicians and others whose profession it is to serve in this way; the increase of work which is thrown upon the clerical staffs of the cathedrals. But I do most firmly believe that what is worth doing here, as everywhere else, is worth doing well; and so it must be done if we never forget that it is done for Him for Whom no devotion can be too deep and no homage too high.

Now a word as to those on whom the responsibility for the maintenance of cathedral worship -and on many of them also the responsibility for the maintenance of the fabric-depends. As is well known, there are several varieties of cathedral foundations, and in some of the newest of them the Bishop acts as Dean. I believe that experience in most cases has shown that this places on the Bishop an almost impossible burden. He cannot really oversee the whole diocese and at the same time deal with the minute points of cathedral work. Sooner or later he must delegate his functions. That means that a cathedral really does need a Dean. Nowadays Chaptersgoverning Chapters, that is-are usually quite small in numbers. And the powers of Deans in different cathedrals are very different. Into details there is no need or space to enter here. But part, though only a very small (and that the last) part, of what Archbishop Benson quoted from Roderic of Zamora (through Van Espen) is still true:

"A Dean succeeds to the government of a Chapter-say, rather, to the guiding of an untameable beast. It is hard and difficult to govern a small house, but great Chapters are so much the worse, because there are as many opinions as there are individuals. If a Dean be charmed with the dignity of his office, let him fear its burdens; let him fear its perils. It is no easy task to recount them."

The burdens cannot be lightened by combining the offices of Bishop and Dean. Said Archbishop Benson, "Let us trust we have heard the last of such proposals."

I cannot go into detail as to the work of each of the Chapters. It must vary according to circumstances, statutes, and duties. I will content myself rather with the spirit in which each should work. We have all heard, no doubt, in fiction or fact, of domineering Deans, of provoking Precentors, of Organists oldfashioned and out of sympathy with modern art. Even Canons may have been cantankerous at times. The only way 
to cure such ills is for each one to take as his motto for all his work some such words as those of Canon Newbolt:

"Let me offer to God and to His spiritual service the powers which are mine in the endowment of my human nature. Let me put at His disposal all that my education has done for me or brought to me. Let me give Him my experience and the result of any success, or the warnings of any failure which life has given me. God, knowing my past, and knowing my future, and with His eye on the work which I am able to do in the present, has put me here: Spartam nactus es, hanc exorna."

I hope I have not spent too long a time on generalities. But I am convinced that it is on such generalities-or, in other words, in the spirit in which our work is done-that the usefulness of cathedrals depends. Important though the use of them in detail is, it is more important still that everything that is done in them, whatever it is, should be done by everyone, Bishop to verger, for the glory of God. Briefly, then, as to the work to be done in cathedrals:

1. The music. The characteristic offering of the cathedral to God is beautiful music. This must be subordinated always to, or rather governed by, the idea of worship. The organist does not play, the minor canon intone, the choir sing, for effect, but for devotion. And what is devoted is the best power of each. Until quite recently, I believe that practically every eminent English musician had been trained in a cathedral. It is of paramount importance that these schools of music, with their local differences and their individual leadership, should continue. Church music has rightly been a profession, and so it should remain. And it should be a properly paid profession.

A sub-head, as it were, to this is the education of the children of the choir. There are great difficulties about this nowadays, and not all cathedrals can support a separate school. I see no reason at all why the choristers should not attend a good local secondary school, and either live with their parents or board with the Precentor or some musical official of the Church.

2. Preaching and lecturing are proper functions of the cathedral body. Lectures on subjects of religious interesthistorical, social, musical, educational-should fall within the functions and the capacity of the members of the cathedral body to deliver. Preaching should be especially cultivated. Those who attend cathedral services expect the preachers to take very special pains to instruct and advise them. Happily for us all, men have ceased to think of cathedrals as comfortable 
refuges for quiet clergymen, and their pulpits as reserved for what Herbert Losinga, the great Bishop-builder of Norwich, called "the drivelling opinions of advancing age." Nor is it old men alone who are capable of such weakness.

3. Special services for diocesan purposes, for guilds and societies, should constantly be organized: the difficulty here is very generally a geographical one, which modern systems of transport may diminish. And, wherever it is possible, each diocesan society should find in some special way, perhaps in some special part of it, the cathedral to be its spiritual home.

4. This leads to a word about the Bishop's relation to the cathedral. It must never be forgotten that it is his church, not merely the Chapter's, or the city's, or the nation's. What his duties in it, his powers in regard to it, the closeness of his connection with it, may be, must depend upon where he lives, what he has to do, what the cathedral statutes are, and other things too. When the commission of 1854 asked the question, "What are the rights of the Bishop with respect to the cathedral church ?" the Chapter of Winchester replied, "None, except as visitor." I am no believer in a cast-iron system. Local varieties are the very breath of a living church. To these Bishops and Chapters should adapt themselves. They should not try to bend or break them to their will. I have known a Bishop who attended the daily services every day when he was at home. I have known a Bishop whose attendances during the year were so few that it was thought better not to keep a record of them. But both, mind you, were very good Bishops; it was the circumstances which differed.

5. It is of great importance, if the English Church is not to lose its ancient reputation for the instructed intelligence of its clergy -and it is in great danger of losing it-that the cathedrals should be places of learning. This depends on the Crown and the Lord Chancellor and the Bishop, in whose hands appointments rest. The cathedral Chapter should not be filled with men who are worked to the bone outside the cathedral or in its own material interests. There should be a home of leisure for men of learning, who shall not only pray, but study. If they are not worried by committees, they will have time for both.

6 . The clergy are likely, but the public are not at all likely, to forget that the cathedrals are the greatest examples of English art which we possess. It is the duty of those who guard them to see that everyone who enters them has the opportunity of studying the glorious architecture which they exhibit. For this reason I am utterly opposed to the closing of any part to any human being. What man has built, man has a right to 
see. Let it never be forgotten that the great architecture of our cathedrals is a lesson in humility as well as in prayer. They were set up in the very contrast to every thought of man's glory or human praise. The greatest is achieved by innumerable acts of self-effacement. The splendour which all see is the result of countless pieces of craftsmanship which no man sees. Again and again you find that detail, decoration, a thought of beauty embodying itself in stone or glass, is set where men do not look for it, where in long centuries no one will praise it. It was set there because no work of man's highest can be great enough to show his humility and love. In our cathedrals the art which made and enriches them, the history which has passed in them, is all consecrated to God. That is why-and not only because he has a right to architecture as well as music-everyone should be allowed to see them freely. But do not let it be thought that this is to turn a cathedral into a museum. I am quite sure that the services of a good verger-and I have experience of very good ones-as well as of a member of the Chapters, are a real, even a necessary, help to a great number of visitors. To let people wander aimlessly about without any effort to direct them to what is good in art, which is of historic interest or of beauty, is to turn the cathedrals into museums. To teach people what is good in architecture is just as valuable as it is to teach them what is good in music, or painting, or literature. A trained guide is indispensable in a cathedral. But he must be one who has the same devotion to God that the builders had, that the worshippers have, that those who live and work in the cathedrals must all have, if they are not to be unworthy of their place.

7. There is the thorny point of fees. No one wishes more than I do to throw all open. But experience proves in some cathedrals that irreparable damage is done where there is no control, and treasurers are insistent in some cases that an entire abolition of fees is impossible. The subject cannot be settled in a paper so brief as this. I must be content to ask everyone who can to read the most admirable sections on the subject in the Primary Charge of the Bishop of Peterborough (S.P.C.K., 1921).

W. H. Hutton.

\section{THE NEW TESTAMENT TEXT}

OF all the tools at the disposal of the student of Christian theology none is so valuable as the text of the New Testament. There we get nearer to Our Lord's mind than anywhere else. All the efforts of destructive criticism in the nineteenth century 